\title{
Geomicrobiological factors that control uranium mobility in the environment: Update on recent advances in the bioremediation of uranium-contaminated sites
}

\author{
Yohey SuzUKI and Takeshi SuKo \\ Research Center for Deep Geological Environments, National Institute of Advanced Industrial \\ Science \& Technology (AIST), 1-1-1 Higashi, Tsukuba, Ibaraki 305-8567, Japan
}

\begin{abstract}
Understanding the behavior of uranium $(\mathrm{U})$ in the environment is essential not only for the protection of aquifers from $U$ contamination but also for predicting the fate of $U$ and other actinides disposed of in deep geological settings. It has long been believed that the redox chemistry of $U$ can be simply predicted by thermodynamics and that the development of a low redox potential is a sufficient condition for $U$ reduction. However, recent studies have demonstrated that redox transformations of $U$ are controlled by kinetic factors that are strongly influenced by microbial activity. Although abiological $U$ oxidation proceeds efficiently under oxygenic conditions, abiological reduction of $\mathrm{U}$ is inhibited by the formation of negatively charged $\mathrm{U}(\mathrm{VI})-\mathrm{CO}_{3}$ complexes that prevail in nature. Phylogenetically diverse microorganisms are capable of enzymatically reducing $\mathrm{U}(\mathrm{VI})-\mathrm{CO}_{3}$ complexes to form $\mathrm{U}(\mathrm{IV})$-bearing minerals such as uraninite $\left(\mathrm{UO}_{2+\mathrm{x}}\right)$. The only abiological pathway currently known for the reduction of $\mathrm{U}(\mathrm{VI})-\mathrm{CO}_{3}$ complexes involves the $\mathrm{Fe}(\mathrm{II})$ monohydroxo surface complex $\equiv \mathrm{Fe}^{\mathrm{III}} \mathrm{OFe}^{\mathrm{II}} \mathrm{OH}^{0}$. This complex is mainly produced by the microbial reduction of $\mathrm{Fe}(\mathrm{III})$ in natural systems. Thus, U(VI) reduction is controlled both directly and indirectly, at least in part, by microbial activity. Several mechanisms of $U$ oxidation under anoxic conditions have been revealed recently by laboratory and field studies. U(IV) is abiologically oxidized by $\mathrm{Fe}(\mathrm{III})$ and $\mathrm{Mn}(\mathrm{IV})$ oxides. Microbial reduction of nitrate to molecular nitrogen, which occurs following the depletion of $\mathrm{O}_{2}$, produces nitrogen intermediates including nitrite $\left(\mathrm{NO}_{2}^{-}\right)$, nitrous oxide $(\mathrm{NO})$, and nitric oxide $\left(\mathrm{N}_{2} \mathrm{O}\right)$. Although the nitrogen intermediates oxidize $\mathrm{U}(\mathrm{IV})$, poorly crystalline $\mathrm{Fe}$ (III)-oxide minerals resulting from the oxidation of aqueous $\mathrm{Fe}$ (II) species by the nitrogen intermediates oxidize U(IV) more efficiently than the nitrogen intermediates alone. Remarkably, the formation of Ca-U(VI)$\mathrm{CO}_{3}$ complexes resulting from increased levels of $\mathrm{Ca}^{2+}$ and/or $\mathrm{HCO}_{3}^{-}$leads to the reoxidation of bioreduced U(IV) under reducing conditions. These geomicrobiological factors pose challenges in manipulating and/or predicting the mobility and fate of $U$ in complex and heterogeneous environmental settings.
\end{abstract}

Keywords: Uranium, Actinides, Radionuclides, Microbial redox transformations, Bioremediation, Geological disposal of nuclear wastes

\section{INTRODUCTION}

Uranium (U) is chemically analogous to other actinides such as plutonium $(\mathrm{Pu})$ and neptunium $(\mathrm{Np})$ in terms of its redox properties and its strong tendency to form complexes with inorganic and organic ligands (Macaskie, 1991; Suzuki and Banfield, 1999; Lloyd and Macaskie, 2000). Thus, U serves as a valuable model for the behavior of actinides in complex natural systems. As $U$ and its decay products are hazardous because of their radioactivity and chemical toxicity (Suzuki and Banfield, 2004; Hu

doi:10.2465/jmps.060322

Y. Suzuki, yohey-suzuki@aist.go.jp Corresponding author et al., 2005), the contamination of soil, sediment, and groundwater with $\mathrm{U}$ is a great environmental threat (Landa and Gray, 1995).

The mobility of $U$ in the environment is mainly controlled by complexation and redox reactions (Langmuir, 1978; Finch and Murakami, 1999). Complexation often leads to the formation of mobile aqueous species or the precipitation of U-bearing minerals (Finch and Murakami, 1999). The redox reactions of $U$ typically involve substantial changes in solubility between the two major oxidation states of U(IV) and U(VI). The reduction of U(VI) to $\mathrm{U}(\mathrm{IV})$ is generally considered to immobilize $\mathrm{U}$ as a result of the formation of $\mathrm{U}(\mathrm{IV})$-bearing minerals such as 
uraninite $\left(\mathrm{UO}_{2+\mathrm{x}}\right)$ (Langmuir, 1978). In turn, the oxidation of $\mathrm{U}(\mathrm{IV})$ to $\mathrm{U}(\mathrm{VI})$ is regarded as mobilizing $\mathrm{U}$ because of the dissolution of U(IV)-bearing minerals. The combination of these reactions appears to determine the mobility and fate of $U$ in natural systems.

Over the past decade, our knowledge of U biogeochemistry has advanced rapidly, partly because the cleanup of U-contaminated subsurface environments where nuclear weapons had been manufactured was given a scientific priority in the USA (National Research Council, 2000). More importantly, the discovery of several species of $\mathrm{Fe}$ (III)-reducing bacteria that can also reduce $\mathrm{U}$ and other radionuclides inspired the concept of a "biogenic redox barrier" to prevent the runoff of radionuclides into downgradient water resources (Gorby and Lovley, 1992; Lovley, 2001). This potentially cost-effective technology is mechanistically based upon the enzymatic activity of indigenous microorganisms to reduce radionuclides, and is stimulated by the injection of nutrients into contaminated aquifers (Lovley, 2001).

This brief review paper aims to summarize the output from tremendous research efforts that have sought to gain a better understanding of biogeochemical processes that impact on the mobility of $U$ and other radionuclides in natural and contaminated settings. The focus is on the redox transformations of $U$ under anaerobic conditions, as these are relevant to the disposal of nuclear wastes in deep geological settings as well as in situ bioremediation. Future directions for the bioremediation of U-contaminated sites and geomicrobiological factors that warrant serious consideration in terms of safety assessments of the geological disposal of nuclear wastes are also suggested.

\section{ABIOLOGICAL PROCESSES THAT CONTROL U REDOX TRANSFORMATIONS}

The abiological oxidation of U(IV) is coupled to the reduction of $\mathrm{O}_{2}, \mathrm{Fe}(\mathrm{III})$, and $\mathrm{Mn}$ (IV) (Langmuir, 1978; Nevin and Lovley, 2000; Wielinga et al., 2000; Fredrickson et al., 2002; Liu et al., 2002). These inorganic reactions are kinetically fast and proceed without any surface catalysts.

Abiological U(VI) reduction by inorganic reductants such as $\mathrm{H}_{2}, \mathrm{H}_{2} \mathrm{~S}$, and aqueous $\mathrm{Fe}(\mathrm{II})$ species proceeds efficiently (Beyenal et al., 2004) unless U(VI) is complexed with carbonate to become an anionic aqueous species (Lovley et al., 1991; Fredrickson et al., 2000). For example, the negatively charged $\mathrm{U}(\mathrm{VI})-\mathrm{CO}_{3}$ complexes $\mathrm{UO}_{2}\left(\mathrm{CO}_{3}\right)_{2}^{2-}$ and $\mathrm{UO}_{2}\left(\mathrm{CO}_{3}\right)_{3}^{4}$, which are the dominant aqueous $\mathrm{U}$ species in most surface and subsurface settings, are not reduced homogeneously by chemical reductants. This has been clearly demonstrated in the laboratory
(Lovley et al., 1991; Liger et al., 1999; Fredrickson et al., 2000; Beyenal et al., 2004) and in a $\mathrm{H}_{2} \mathrm{~S}$-rich stratified water column in the Black Sea (Anderson, 1987). These findings highlight the importance of recognizing the fact that the reduction of $\mathrm{U}(\mathrm{VI})$ is not solely controlled by thermodynamic factors.

In sharp contrast to the resistance of $\mathrm{U}(\mathrm{VI})-\mathrm{CO}_{3}$ complexes to homogeneous reduction in solution, $\mathrm{U}(\mathrm{VI})^{-}$ $\mathrm{CO}_{3}$ complexes that diffuse into naturally organic-rich sediments are reduced instantaneously. The traditional explanation for this change is that organic matter and iron-sulfide minerals that are associated with U(IV)-bearing minerals in many sedimentary $\mathrm{U}$-ore deposits catalyze U(VI) reduction (see Mohagheghi et al., 1985 and references therein). U(VI) reduction by organic matter has been shown experimentally to be ineffective at temperatures below $120{ }^{\circ} \mathrm{C}$, even for noncarbonated U(VI) species (Nakashima et al., 1984). Although U(VI) reduction by pyrite has been demonstrated for noncarbonated species (Wersin et al., 1994), $\mathrm{U}(\mathrm{VI})-\mathrm{CO}_{3}$ complexes are not reduced efficiently by iron-sulfide minerals (E.E. Roden, personal communication).

To date, all known processes for the abiological reduction of $\mathrm{U}(\mathrm{VI})-\mathrm{CO}_{3}$ complexes involve $\mathrm{Fe}(\mathrm{III})$-oxide minerals (Fredrickson et al., 2000; Behrends and Van Cappellen, 2005; Jeon et al., 2005). Fe(III)-oxide minerals involved in $\mathrm{U}$ reduction include magnetite $\left(\mathrm{Fe}_{3} \mathrm{O}_{4}\right)$, goethite $(\alpha-\mathrm{FeOOH})$, and hematite $\left(\alpha-\mathrm{Fe}_{2} \mathrm{O}_{3}\right)$. Abiological $\mathrm{U}(\mathrm{VI})$ reduction in the presence of the $\mathrm{Fe}(\mathrm{III})$-oxide minerals requires aqueous $\mathrm{Fe}(\mathrm{II})$ species, and the $\mathrm{Fe}(\mathrm{II})$ monohydroxo surface complex $\equiv \mathrm{Fe}^{\mathrm{III}} \mathrm{OFe}^{\mathrm{II}} \mathrm{OH}^{0}$ is considered to be a reductant in the reduction of U(VI) (Liger et al., 1999). Magnetite appears to be a more efficient component of $\mathrm{U}(\mathrm{VI})$ reduction than hematite under certain experimental conditions (Behrends and Van Cappellen, 2005).

Humic substances, which are a mixture of naturally occurring organic compounds, are known to serve as electron shuttles between electron-donating and electronaccepting pairs. It is well established that humic substances and the humic analogue anthraquinone-2,6-disulfonate (AQDS) enhance the rate and extent of biological and abiological reduction of U(VI) (Nevin and Lovley, 2000; Jeon et al., 2004). In the opposite direction, humic substances accelerate the rate of abiological U(IV) oxidation by $\mathrm{O}_{2}$ by up to an order of magnitude ( $\mathrm{Gu}$ et al., 2005b).

Recently, $\mathrm{Ca}-\mathrm{U}(\mathrm{VI})-\mathrm{CO}_{3}$ complexes such as $\mathrm{CaUO}_{2}\left(\mathrm{CO}_{3}\right)_{3}^{2-}$ and $\mathrm{Ca}_{2} \mathrm{UO}_{2}\left(\mathrm{CO}_{3}\right)_{3}$ were discovered (Bernhard et al., 1996, Kalmykov and Choppin, 2000; Bernhard et al., 2001). The formation of $\mathrm{Ca}-\mathrm{U}(\mathrm{VI})-\mathrm{CO}_{3}$ complexes with a lower redox potential than that of $\mathrm{U}(\mathrm{VI})-\mathrm{CO}_{3}$ com- 


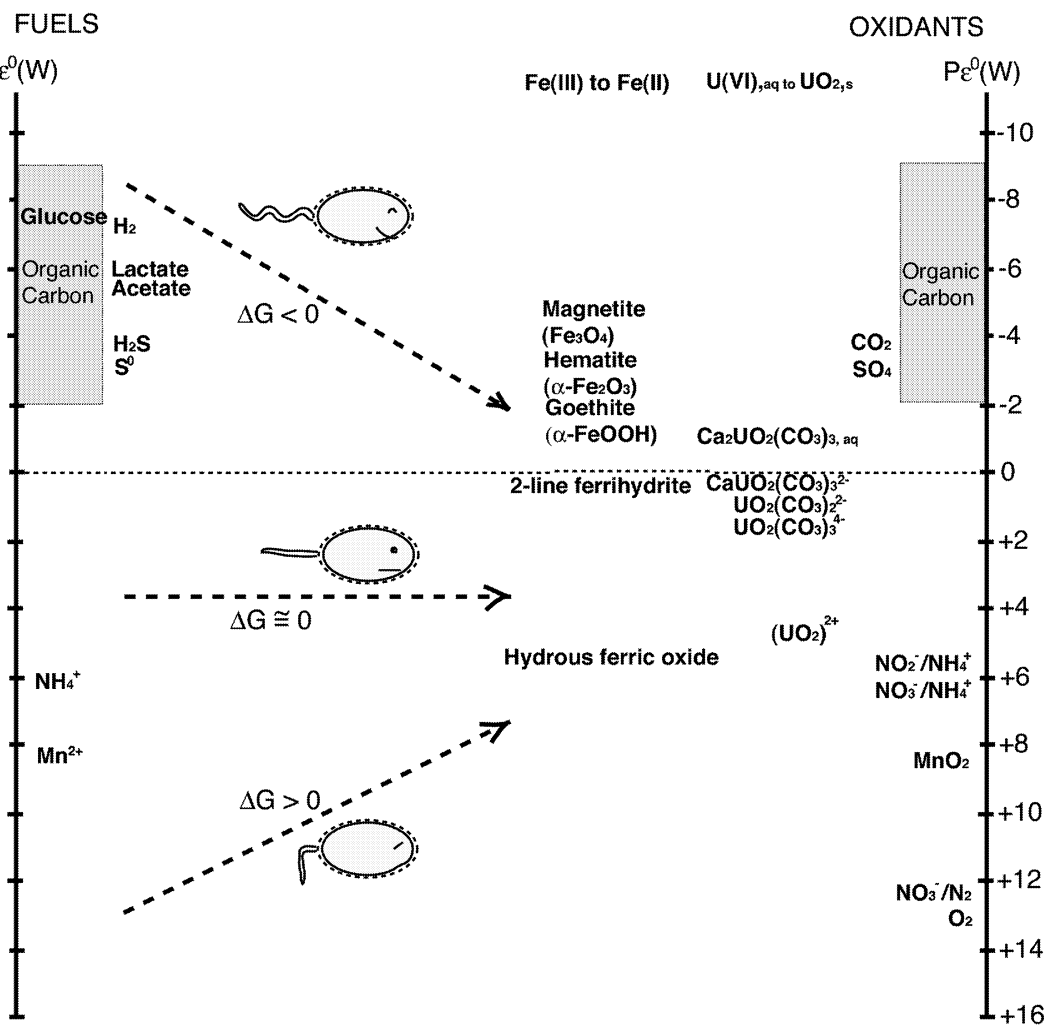

Adapted from Nealson \& Stahl (1997)
Figure 1. Redox potentials of electron donors (fuels) and acceptors (oxidants) commonly used for microbial respiration at a circumneutral $\mathrm{pH}$. Most values are adapted from Nealson and Stahl (1997), except for those between various forms of solid Fe(III) oxides and $\mathrm{Fe}^{2+}$ and those between various aqueous $\mathrm{U}(\mathrm{VI})$ species and the solid $\mathrm{UO}_{2+\mathrm{x}}$, which were calculated by Roden (2003) and Brooks et al. (2003), respectively. plexes (see Fig. 1) substantially decreases the rate and extent of enzymatic U(VI) reduction (Brooks et al., 2003). It is not certain if the formation of $\mathrm{Ca}-\mathrm{U}(\mathrm{VI})-\mathrm{CO}_{3}$ complexes also inhibits the chemical reduction of $\mathrm{U}(\mathrm{VI})$ by the Fe(II) monohydroxo surface complex.

\section{DIRECT ENZYMATIC CONTROL OF THE REDOX TRANSFORMATIONS OF U}

It has long been known that, at an acidic $\mathrm{pH}$ where U(IV) becomes soluble, the autotrophic bacterium Acidithiobacillus ferrooxidans (formerly Thiobacillus ferrooxidans) conserves energy via the aerobic oxidation of U(IV) (Dispirito and Tuovinen, 1982). In contrast to A. ferrooxidans, $\mathrm{Fe}(\mathrm{III})$-reducing Geobacter metallireducens, nitratereducing Klebsiella sp., and sulfur-oxidizing nitratereducing Thiobacillus denitrificans enzymatically oxidize $\mathrm{U}(\mathrm{IV})$ at a near-neutral $\mathrm{pH}$ under anaerobic conditions (Finneran et al., 2002b; Beller, 2005; Senko et al., 2005a). The enzymatic U(IV) oxidation is coupled to nitrate reduction and is not linked to energy conservation required for cell growth. The phylogenetic relationships between microorganisms that enzymatically oxidize U(IV) are shown in Figure 2.

Since the first report on the ability of some Fe(III)- reducing bacteria to enzymatically reduce U(VI) (Lovley et al., 1991), the number of known U(VI)-reducing microorganisms has increased (Shelobolina et al., 2004; Suzuki et al., 2004). As shown in Figure 2, more than 25 species of phylogenetically diverse prokaryotes are known to mediate enzymatic U(VI) reduction, including a hyperthermophilic archaeon (Kashefi and Lovley, 2000), thermophilic bacteria (Kieft et al., 1999), mesophilic $\mathrm{Fe}(\mathrm{III})$-reducing bacteria (Lovley et al., 1991, Coates et al., 1998; Coates et al., 2001), mesophilic sulfate-reducing bacteria (Lovley and Phillips, 1992; Lovley et al., 1993; Tebo and Obraztsova, 1998; Suzuki et al., 2005), fermentative bacteria (Francis et al., 1994; Sani et al., 2002), a heterotrophic bacterium (McLean and Beveridge, 2001), and an acidotolerant bacterium (Shelobolina et al., 2004). Some of these have been shown to grow using $\mathrm{U}(\mathrm{VI})$ as a sole terminal electron acceptor (Lovley et al., 1991; Tebo and Obraztsova, 1998; Pietzsch et al., 1999). Considering the overwhelming number of Fe(III)-reducing bacteria, many of which have not been examined for their U(VI)-reduction abilities, there may be many more U(VI)-reducing bacteria than are currently known.

Although U(VI)-reducing microorganisms typically reduce $\mathrm{U}(\mathrm{VI})$-carbonate species and form $\mathrm{U}(\mathrm{IV})^{-}$-oxide minerals such as uraninite, the thermophilic bacterium 


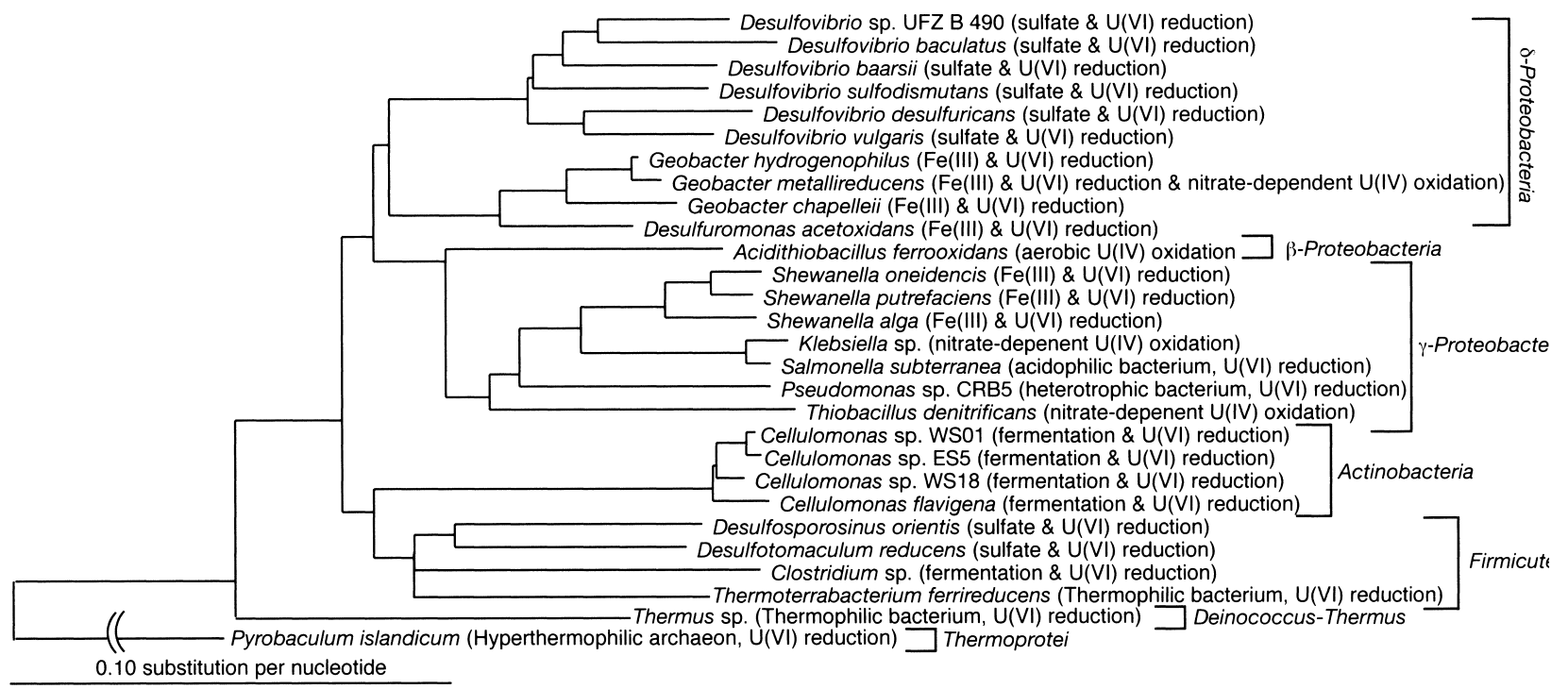

Figure 2. Phylogenetic relationships between microorganisms that mediate the enzymatic reduction and/or oxidation of U. The major physiological characteristics and types of $U$ redox transformations that are enzymatically mediated by the microorganisms are provided in parentheses. The taxonomic affiliations of the microorganisms at the order or suborder level are shown.

Thermoterrabacterium ferrireducens was recently shown to reduce the $\mathrm{U}(\mathrm{VI})$-phosphate mineral uramphite $\left[\mathrm{NH}_{4}\right.$ $\left(\mathrm{UO}_{2}\right)\left(\mathrm{PO}_{4}\right) \cdot 3 \mathrm{H}_{2} \mathrm{O}$ ] and to form the U(IV)-phosphate mineral ningyoite $\left[\mathrm{CaU}\left(\mathrm{PO}_{4}\right)_{2} \cdot \mathrm{H}_{2} \mathrm{O}\right]$ (Khijniak et al. 2005). It has also been documented that sulfate-reducing Desulfosporosinus spp. are not capable of reducing $\mathrm{U}(\mathrm{VI})^{-}$carbonate complexes (Suzuki et al., 2004). Exceptionally, fermentative Cellulomonas spp. mediate $\mathrm{U}(\mathrm{VI})$ reduction by using unknown internal electron donors stored during the enrichment, whereas the other $\mathrm{U}(\mathrm{VI})$-reducing microorganisms use external electron donors (molecular hydrogen, glucose, lactate, pyruvate, ethanol, sucrose, or acetate).

\section{EFFECTS OF MICROBIAL RESPIRATION ON THE REDOX TRANSFORMATIONS OF U}

In natural systems, the extent and rate of the redox transformations of $U$ are determined by the intricate interplay between biological and abiological processes (Suzuki et al., 2005). The redox potentials of electron acceptors for microbial respiration are generally considered to constrain the order of terminal electron acceptors utilized by complex microbial communities (Nealson and Stahl, 1997). In principle, oxidation of an electron donor coupled to the reduction of an electron acceptor with a higher redox potential is more favorable for microbial energy conservation than is the counterpart with a lower redox potential (Fig. 1). Following this principle, the supply of $\mathrm{O}_{2}$ first promotes the growth of aerobic microorganisms in natural systems (Nealson and Stahl, 1997). According to the redox ladder drawn in Figure 1, nitrate is the next most favorable electron acceptor for microbial respiration (Nealson and Stahl, 1997). In the case of Fe(III), the chemical form of $\mathrm{Fe}(\mathrm{III})$ has a pronounced influence on the redox potential (Roden, 2003b). For instance, the redox potential of hydrous ferric oxide is much higher than that of other solid Fe(III)-oxide minerals, whereas magnetite, hematite, and goethite have redox potentials approaching or even lower than that of sulfate (Fig. 1). The persistence of some $\mathrm{Fe}(\mathrm{III})$ - oxide minerals from abiological and biological reduction probably leads to the coexistence of aqueous $\mathrm{Fe}(\mathrm{II})$ species and $\mathrm{Fe}(\mathrm{III})$ minerals, which appears to promote abiological reduction of $\mathrm{U}(\mathrm{VI})$ by the $\mathrm{Fe}(\mathrm{II})$ monohydroxo surface complex. The occurrence of microbial sulfate reduction depends on the form of $\mathrm{Fe}$ (III) accessible to microbial respiration. Accordingly, methanogenesis, which involves the reduction of $\mathrm{CO}_{2}$ to $\mathrm{CH}_{4}$, is less energetically favorable than sulfate reduction.

These microbial respiratory processes directly and indirectly impact upon the consumption and generation of the oxidant as well as the reductant during the redox transformations of U. Direct microbial effects include the consumption of oxidants such as $\mathrm{O}_{2}$ and $\mathrm{Fe}(\mathrm{III})$ and the production of the chemical reductant $\equiv \mathrm{Fe}^{\mathrm{III}} \mathrm{OFe}^{\mathrm{II}} \mathrm{OH}^{0}$. Microbial reduction of nitrate and sulfate indirectly influences the redox transformations of U. Although nitrate itself is not capable of oxidizing Fe(II) (Weber et al., 2001) and U(IV) (Senko et al., 2002), nitrate-reducing microorganisms produce nitrite $\left(\mathrm{NO}_{2}^{-}\right)$, nitrous oxide $(\mathrm{NO})$, and nitric oxide $\left(\mathrm{N}_{2} \mathrm{O}\right)$, which in turn chemically oxidize $\mathrm{Fe}(\mathrm{II})$ and U(IV) (Senko et al., 2002). 
$\mathrm{H}_{2} \mathrm{~S}$ produced by sulfate-reducing microorganisms has inhibitory effects on abiological U(VI) reduction because of the precipitation of iron-sulfide minerals on the surface of residual $\mathrm{Fe}(\mathrm{III})$ - oxide minerals (Neal et al., 2001). Thus far, enzymatic U(VI) reduction is the only known mechanism by which $\mathrm{U}(\mathrm{VI})$ is efficiently reduced under highly sulfidogenic conditions. Although sulfatereducing microorganisms belong to phylogenetically diverse groups, only those members of the genera Desulfovibrio are known to mediate the enzymatic reduction of U(VI) (Lovley et al., 1993), with the exception of two species of spore-forming sulfate-reducing bacteria (Tebo and Obraztsova 1998; Suzuki et al., 2004). It should be noted that our knowledge of the ability of sulfate-reducing microorganisms to accomplish enzymatic $\mathrm{U}(\mathrm{VI})$ reduction is too sparse to identify sulfate-reducing microorganisms that reduce $\mathrm{U}$ under sulfidogenic conditions.

A limited number of methanogenic microorganisms are capable of enzymatically reducing Fe(III)-oxide minerals and thereby potentially compete with $\mathrm{Fe}$ (III)-reducing bacteria for $\mathrm{Fe}$ (III)-oxide minerals as an electron acceptor (Bond and Lovley 2002; Roden 2003a; Roden and Wetzel 2003). As methanogenic microorganisms are not known for their enzymatic $U$ reduction, the predominance of methanogenic microorganisms over $\mathrm{Fe}(\mathrm{III})^{-}$ reducers may substantially lower the rate and extent of $\mathrm{U}(\mathrm{VI})$ reduction.

\section{REDOX TRANSFORMATIONS OF U IN U-CONTAMINATED SETTINGS}

Over the past five years, attempts have been made to study the biogeochemical cycling of $U$ under conditions more relevant to the complexity of environmental settings. The level of $U$ in natural systems is generally too low to reveal the mechanisms of the redox transformations of U. Accordingly, U-contaminated settings such as mine sites, mill tailings, and sites where nuclear weapons have been manufactured have been studied directly by field observations or indirectly in laboratory experiments in which sediment and water samples collected from the field have been used to simulate in situ biogeochemical processes. The laboratory amendment of field sediments with organic substrates as electron donors to stimulate anaerobic microbial respiration typically results in significant removal of $U$ from the pore water within a short period (< 1 month) (Abdelouas et al., 1999; Abdelouas et al., 2000; Finneran et al., 2002a; Finneran et al., 2002b; Suzuki et al., 2002; Elias et al., 2003a; Nevin et al., 2003; Suzuki et al., 2003; North et al., 2004; Gu et al., 2005a; Senko et al., 2005b; Tokunaga et al., 2005; Wan et al., 2005). No U(VI) reduction has been observed in the abio- logical controls, which strongly suggests that $\mathrm{U}(\mathrm{VI})$ reduction is biologically mediated. This is indeed the case when organic electron donors such as acetate and ethanol are injected into shallow $\mathrm{U}$-contaminated aquifers to enhance the respiration of indigenous microorganisms (Senko et al., 2002; Anderson et al., 2003; Istok et al., 2004). In all examples, U(VI) reduction was accompanied by the complete depletion of $\mathrm{O}_{2}$ and nitrate (Senko et al., 2005b).

Microbial populations associated with the stimulated $\mathrm{U}(\mathrm{VI})$ reduction have been characterized in a number of studies using molecular biological techniques (Holmes et al., 2002; Nevin et al., 2003; Petrie et al., 2003; Suzuki et al., 2003; North et al., 2004; Vrionis et al., 2005). U(VI) reduction is correlated with the enrichment of microorganisms related to known $\mathrm{Fe}(\mathrm{III})^{-}$and $\mathrm{U}(\mathrm{VI})$-reducing Geobacter spp. (Holmes et al., 2002; Anderson et al., 2003). Under sulfate-rich conditions, sulfate-reducing Desulfosporosinus spp. appear to be associated with the stimulated U(VI) reduction (Nevin et al., 2003; Suzuki et al., 2003). In slightly acidic sediments, Anaeromycobacter spp. belonging to Deltaproteobacteria, as well as Geobacter spp., appear to play a major role in $\mathrm{Fe}(\mathrm{III})$ and $\mathrm{U}(\mathrm{VI})$ reduction, although the ability of Anaeromycobacter spp. to enzymatically reduce $\mathrm{U}(\mathrm{VI})$ has not been demonstrated in pure culture (Petrie et al., 2003; North et al., 2004).

Once accessible $\mathrm{Fe}(\mathrm{III})$-oxide minerals are depleted, sulfate-reducing microorganisms outcompete $\mathrm{Fe}(\mathrm{III})^{-}$ reducing bacteria for electron donors. The rate and extent of $\mathrm{U}(\mathrm{VI})$ reduction decreases in $\mathrm{U}$-contaminated aquifers where sulfate-reducing bacteria incapable of enzymatic $\mathrm{U}(\mathrm{VI})$ reduction are dominant over Fe(III)-reducing bacteria (Anderson et al., 2003; Ortiz-Bernad et al., 2004; Vrionis et al., 2005). This result also suggests that in situ activity of sulfate-reducing bacteria capable of enzymatic $\mathrm{U}(\mathrm{VI})$ reduction is necessary for efficient $\mathrm{U}(\mathrm{VI})$ reduction under sulfidogenic conditions.

Although microorganisms capable of reducing $\mathrm{U}(\mathrm{VI})$ are widespread in the shallow subsurface, their in situ activity is constrained by high concentrations of competing electron acceptors, microbial competition for electron donors, and other site-specific factors. The addition of nitrate to sediments and aquifers that previously underwent microbial $\mathrm{U}(\mathrm{VI})$ reduction results in rapid oxidation and subsequent dissolution of bioreduced U(IV) minerals (Finneran et al., 2002b; Senko et al., 2002; Elias et al., 2003b). During the microbial reduction of nitrate to nitrogen gas, intermediates such as nitrite, nitrous oxide, and nitric oxide are produced. As mentioned above, all of these intermediates abiologically oxidize U(IV), but the rates of U(IV) oxidation are slow. An increased rate of 
$\mathrm{U}(\mathrm{IV})$ oxidation coupled to microbial nitrate reduction is observed when aqueous $\mathrm{Fe}$ (II) is added to a solution containing U(IV) and nitrite. Fe(III)-oxide minerals produced during the chemical oxidation of $\mathrm{Fe}$ (II) by nitrite are poorly crystalline and oxidize U(IV) efficiently. In contrast, enzymatic $\mathrm{Fe}(\mathrm{II})$ oxidation coupled to nitrate reduction typically leads to the formation of crystalline Fe(III)oxide minerals that exhibit a slow rate of U(IV) oxidation. As direct U(IV) oxidation by the enzymatic activity of nitrate-reducing G. metallireducens, Klebsiella sp., and $T$. denitrificans in pure culture is also kinetically slow, the rapid oxidation of U(IV) observed following the addition of nitrate might be attributed to the chemical formation of poorly crystalline $\mathrm{Fe}(\mathrm{III})$-oxide minerals as a consequence of microbial nitrate reduction.

The formation of $\mathrm{Ca}-\mathrm{U}(\mathrm{VI})-\mathrm{CO}_{3}$ complexes, as described above, has recently been demonstrated to affect the mobility of $U$ under environmentally relevant conditions (Wan et al., 2005). Long-term amendment of U-contaminated sediments in the laboratory with organic electron donors (100-500 days) results in reoxidation of the initially bioreduced U(IV) under reducing conditions (Wan et al., 2005). Synchrotron-based spectroscopy reveals the subsequent formation of $\mathrm{Ca}-\mathrm{U}-\mathrm{CO}_{3}$ complexes due to increased levels of microbial metabolites including bicarbonate (Wan et al., 2005).

\section{FUTURE DIRECTIONS IN THE BIOREMEDIA- TION OF U-CONTAMINATED SITES}

Suzuki et al. (2002) clearly demonstrated that the products of the microbial reduction of U(VI) comprise nanoparticulates of uraninite ranging in size from 1 to $3 \mathrm{~nm}$. It was also revealed that the chemical reduction of U(VI) by the $\mathrm{Fe}$ (II) monohydroxo surface complex $\equiv \mathrm{Fe}^{\mathrm{III}} \mathrm{OFe}^{\mathrm{II}} \mathrm{OH}^{0}$ on goethite surfaces results in the formation of uraninite nanoparticulates with a similar size range (Fredrickson et al., 2000). These findings explain the instantaneous reoxidation of U(IV) as a result of subsequent changes in geochemical conditions. There appears to be a risk that the reoxidation of $\mathrm{U}(\mathrm{IV})$ after prolonged treatment can lead to the release of highly $\mathrm{U}$-enriched plumes through aquifers to downgradient water resources. Abdelouas et al. (1999) found that bioreduced U(IV) is protected from oxidation by $\mathrm{O}_{2}$ in the presence of iron-sulfide minerals. Senko et al. (2005b) examined the effects of the concentrations of nitrate and reducing compounds on nitrate-dependent U(IV) oxidation and demonstrated that U(IV) oxidation is inhibited when reducing compounds, including acetate, $\mathrm{H}_{2} \mathrm{~S}$, aqueous $\mathrm{Fe}(\mathrm{II})$, and iron-sulfide minerals, are present in excess relative to nitrate. Among the tested reducing compounds, aqueous $\mathrm{Fe}$ (II) is the most effective inhibitor and acetate is a relatively poor inhibitor (Senko et al., 2005b). The inhibitory role of reducing compounds in U(IV) oxidation might explain the intimate association of U(IV) with iron-sulfide minerals and organic matter in numerous sedimentary U-ore deposits. Further investigation is required to better understand the geomicrobiological factors that control the long-term stabilities of the bioremediation products of $\mathrm{U}(\mathrm{IV})$.

\section{IMPLICATIONS FOR SAFETY ASSESSMENTS OF THE GEOLOGICAL DISPOSAL OF NUCLEAR WASTE}

In safety assessments of the geological disposal of nuclear waste, redox-sensitive radionuclides are predicted to be reduced and subsequently precipitated as low-solubility minerals under reducing conditions, based on their thermodynamic properties. As described above, the development of a low redox potential is NOT a sufficient condition for the reduction of $\mathrm{U}(\mathrm{VI})$ and many other radionuclides (Lloyd and Macaskie, 2000). Furthermore, it is obvious that various geomicrobiological factors impede the chemical and biological reduction of $\mathrm{U}(\mathrm{VI})$ and that the reductive precipitation of $\mathrm{U}(\mathrm{VI})$ and $\mathrm{Tc}(\mathrm{VII})$ leads to the formation of nanoparticulates (Wildung et al., 2000). Admittedly, we have just begun to unveil the complexity and heterogeneity of the redox transformations of $U$ and other radionuclides in environmental settings. This is a critical first step in identifying key factors that control the rate and extent of the redox reactions of radionuclides under conditions relevant to subsurface settings where nuclear waste will potentially be disposed of. In terms of the next step, a conceptual and numerical model must be developed to accommodate those geomicrobiological and hydrological parameters that have a strong influence on the transport and fate of radionuclides in subsurface settings (Roden and Scheibe, 2005).

\section{REFERENCES}

Abdelouas, A., Lutze, W. and Nuttall, H.E. (1999) Oxidative dissolution of uraninite precipitated on Navajo sandstone. Journal of Contaminant Hydrology, 36, 353-375.

Abdelouas, A., Lutze, W., Gong, W.L., Nuttall, E.H., Strietelmeier, B.A. and Travis, B.J. (2000) Biological reduction of uranium in groundwater and subsurface soil. Science of the Total Environment, 250, 21-35.

Anderson, R.F. (1987) Redox Behavior of Uranium in an Anoxic Marine Basin. Uranium, 3,145-164.

Anderson, R.T., Vrionis, H.A., Ortiz-Bernad, I., Resch, C.T., Long, P.E., Dayvault, R., Karp, K., Marutzky, S., Metzler, D.R., Peacock, A., White, D.C., Lowe, M. and Lovley, D.R. (2003) Stimulating the in situ activity of Geobacter species to remove uranium from the groundwater of a uranium-con- 
taminated aquifer. Applied and Environmental Microbiology, 69, 5884-5891.

Behrends, T. and Van Cappellen, P. (2005) Competition between enzymatic and abiotic reduction of uranium(VI) under iron reducing conditions. Chemical Geology, 220, 315-327.

Beller, H.R. (2005) Anaerobic, nitrate-dependent oxidation of U(IV) oxide minerals by the chemolithoautotrophic bacterium Thiobacillus denitrificans. Applied and Environmental Microbiology, 71, 2170-2174.

Bernhard, G., Geipel, G., Brendler, V. and Nitsche, H. (1996) Speciation of uranium in seepage waters of a mine tailing pile studied by time-resolved laser-induced fluorescence spectroscopy (TRLFS). Radiochimica Acta, 74, 87-91.

Bernhard, G., Geipel, G., Reich, T., Brendler, V., Amayri, S. and Nitsche, H. (2001) Uranyl(VI) carbonate complex formation: Validation of the $\mathrm{Ca}_{2} \mathrm{UO}_{2}\left(\mathrm{CO}_{3}\right)_{(3) \text { (aq.) }}$ species. Radiochimica Acta, 89, 511-518.

Beyenal, H., Sani, R.K., Peyton, B.M., Dohnalkova, A.C., Amonette, J.E. and Lewandowski, Z. (2004) Uranium immobilization by sulfate-reducing biofilms. Environmental Science \& Technology, 38, 2067-2074.

Bond, D.R., Lovley, D.R. (2002) Reduction of Fe(III) oxide by methanogens in the presence and absence of extracellular quinones. Environmental Microbiology, 4, 115-124.

Brooks, S.C., Fredrickson, J.K., Carroll, S.L., Kennedy, D.W., Zachara, J.M., Plymale, A.E., Kelly, S.D., Kemner, K.M. and Fendorf, S. (2003) Inhihition of bacterial U(VI) reduction by calcium. Environmental Science \& Technology, 37, 18501858.

Coates, J.D., Councell, T., Ellis, D.J. and Lovley, D.R. (1998) Carbohydrate oxidation coupled to $\mathrm{Fe}(\mathrm{III})$ reduction, a novel form of anaerobic metabolism. Anaerobe, 4, 277-282.

Coates, J.D., Bhupathiraju, V.K., Achenbach, L.A., McInerney, M.J. and Lovley, D.R. (2001) Geobacter hydrogenophilus, Geobacter chapellei and Geobacter grbiciae, three new, strictly anaerobic, dissimilatory $\mathrm{Fe}(\mathrm{III})$-reducers. International Journal of Systematic and Evolutionary Microbiology, 51, 581-588.

Dispirito, A.A. and Tuovinen, O.H. (1982) Uranous Ion Oxidation and Carbon-Dioxide Fixation by Thiobacillus ferrooxidans. Archives of Microbiology, 133, 28-32.

Elias, D.A., Krumholz, L.R., Wong, D., Long, P.E. and Suflita, J.M. (2003a) Characterization of microbial activities and $U$ reduction in a shallow aquifer contaminated by uranium mill tailings. Microbial Ecology, 46, 83-91.

Elias, D.A., Senko, J.M. and Krumholz, L.R. (2003b) A procedure for quantitation of total oxidized uranium for bioremediation studies. Journal of Microbiological Methods, 53, 343-353.

Finch, R.J. and Murakami, T. (1999) Systematics and paragenesis of uranium minerals. In Uranium: mineralogy, geochemistry and the environment (Burns, P.C. and Finch, R. Eds.). Reviews in Mineralogy, Mineralogical Society of America, Washington D.C., 38, 91-179.

Finneran, K.T., Anderson, R.T., Nevin, K.P. and Lovley, D.R. (2002a) Potential for Bioremediation of uranium-contaminated aquifers with microbial U(VI) reduction. Soil \& Sediment Contamination, 11, 339-357.

Finneran, K.T., Housewright, M.E. and Lovley, D.R. (2002b) Multiple influences of nitrate on uranium solubility during bioremediation of uranium-contaminated subsurface sediments. Environmental Microbiology, 4, 510-516.

Francis, A.J., Dodge, C.J., Lu, F.L., Halada, G.P. and Clayton, C.R.
(1994) Xps and Xanes Studies of Uranium Reduction by Clostridium Sp. Environmental Science \& Technology, 28, 636-639.

Fredrickson, J.K., Zachara, J.M., Kennedy, D.W., Duff, M.C., Gorby, Y.A., Li, S.M.W. and Krupka, K.M. (2000) Reduction of U(VI) in goethite (alpha-FeOOH) suspensions by a dissimilatory metal-reducing bacterium. Geochimica et Cosmochimica Acta, 64, 3085-3098.

Fredrickson, J.K., Zachara, J.M., Kennedy, D.W., Liu, C.X., Duff, M.C., Hunter, D.B. and Dohnalkova, A. (2002) Influence of Mn oxides on the reduction of uranium(VI) by the metalreducing bacterium Shewanella putrefaciens. Geochimica et Cosmochimica Acta, 66, 3247-3262.

Gorby, Y.A. and Lovley, D.R. (1992) Enzymatic Uranium Precipitation. Environmental Science \& Technology, 26, 205207.

Gu, B.H., Wu, W.M., Ginder-Vogel, M.A., Yan, H., Fields, M.W., Zhou, J., Fendorf, S., Criddle, C.S. and Jardine, P.M. (2005a) Bioreduction of uranium in a contaminated soil column. Environmental Science \& Technology, 39, 4841-4847.

Gu, B.H., Yan, H., Zhou, P., Watson, D.B., Park, M. and Istok, J. (2005b) Natural humics impact uranium bioreduction and oxidation. Environmental Science \& Technology, 39, 52685275.

Holmes, D.E., Finneran, K.T., O’Neil, R.A. and Lovley, D.R. (2002) Enrichment of members of the family Geobacteraceae associated with stimulation of dissimilatory metal reduction in uranium-contaminated aquifer sediments. Applied and Environmental Microbiology, 68, 2300-2306.

Hu, P., Brodie, E.L., Suzuki, Y., McAdams, H.H. and Andersen, G.L. (2005) Whole-genome transcriptional analysis of heavy metal stresses in Caulobacter crescentus. Journal of Bacteriology, 187, 8437-8449.

Istok, J.D., Senko, J.M., Krumholz, L.R., Watson, D., Bogle, M.A., Peacock, A., Chang, Y.J. and White, D.C. (2004) In situ bioreduction of technetium and uranium in a nitrate-contaminated aquifer. Environmental Science \& Technology, 38, 468-475.

Jeon, B.H., Dempsey, B.A., Burgos, W.D., Barnett, M.O. and Roden, E.E. (2005) Chemical reduction of U(VI) by Fe(II) at the solid-water interface using natural and synthetic Fe(III) oxides. Environmental Science \& Technology, 39, 56425649.

Jeon, B.H., Kelly, S.D., Kemner, K.M., Barnett, M.O., Burgos, W.D., Dempsey, B.A. and Roden, E.E. (2004) Microbial reduction of $\mathrm{U}(\mathrm{VI})$ at the solid-water interface. Environmental Science \& Technology, 38, 5649-5655.

Kalmykov, S.N. and Choppin, G.R. (2000) Mixed $\mathrm{Ca}^{2+} / \mathrm{UO}_{2}^{2+} / \mathrm{CO}_{3}^{2-}$ complex formation at different ionic strengths. Radiochimica Acta, 88, 603-606.

Kashefi, K. and Lovley, D.R. (2000) Reduction of Fe(III), Mn(IV), and toxic metals at 100 degrees $\mathrm{C}$ by Pyrobaculum islandicum. Applied and Environmental Microbiology, 66, 10501056.

Khijniak, T.V., Slobodkin, A.I., Coker, V., Renshaw, J.C., Livens, F.R., Bonch-Osmolovskaya, E.A., Birkeland, N.K., Medvedeva-Lyalikova, N.N. and Lloyd, J.R. (2005) Reduction of uranium(VI) phosphate during growth of the thermophilic bacterium Thermoterrabacterium ferrireducens. Applied and Environmental Microbiology, 71, 6423-6426.

Kieft, T.L., Fredrickson, J.K., Onstott, T.C., Gorby, Y.A., Kostandarithes, H.M., Bailey, T.J., Kennedy, D.W., Li, S.W., 
Plymale, A.E., Spadoni, C.M. and Gray, M.S. (1999) Dissimilatory reduction of $\mathrm{Fe}(\mathrm{III})$ and other electron acceptors by a Thermus isolate. Applied and Environmental Microbiology, 65, 1214-1221.

Landa, E.R. and Gray, J.R. (1995) Us Geological SurveyResearch on the Environmental Fate of Uranium Mining and Milling Wastes. Environmental Geology, 26, 19-31.

Langmuir, D. (1978) Uranium solution-mineral equilibria at lowtemperatures with applications to sedimentary ore-deposits. Geochimica et Cosmochimica Acta, 42, 547-569.

Liger, E., Charlet, L., Van Cappellen, P. (1999) Surface catalysis of uranium(VI) reduction by iron(II). Geochimica et Cosmochimica Acta, 63, 2939-2955.

Liu, C.X., Zachara, J.M., Fredrickson, J.K., Kennedy, D.W. and Dohnalkova, A. (2002) Modeling the inhibition of the bacterial reduction of $\mathrm{U}(\mathrm{VI})$ by beta- $\mathrm{MnO}_{2(\mathrm{~S})(\mathrm{g})}$. Environmental Science \& Technology, 36, 1452-1459.

Lloyd, J.R. and Macaskie, L.E. (2000) Bioremediation of radionuclide-contaminated wastewaters. In Environmental MicrobeMetal Interactions (Lovley D.R. Ed.). ASM Press, Washington, D.C., 277-327.

Lovley, D.R. (2001) Bioremediation - Anaerobes to the rescue. Science, 293, 1444-1446.

Lovley, D.R., Phillips, E.J.P., Gorby, Y.A. and Landa, E.R. (1991) Microbial Reduction of Uranium. Nature, 350, 413-416.

Lovley, D.R. and Phillips, E.J.P. (1992) Reduction of Uranium by Desulfovibrio desulfuricans. Applied and Environmental Microbiology, 58, 850-856.

Lovley, D.R., Roden, E.E., Phillips, E.J.P. and Woodward, J.C. (1993) Enzymatic Iron and Uranium Reduction by SulfateReducing Bacteria. Marine Geology, 113, 41-53.

Macaskie, L.E. (1991) The Application of Biotechnology to the Treatment of Wastes Produced from the Nuclear-Fuel Cycle - Biodegradation and Bioaccumulation as a Means of Treating Radionuclide-Containing Streams. Critical Reviews in Biotechnology, 11, 41-112.

McLean, J. and Beveridge, T.J. (2001) Chromate reduction by a pseudomonad isolated from a site contaminated with chromated copper arsenate. Applied and Environmental Microbiology, 67, 1076-1084.

Mohagheghi, A., Updegraff, D.M. and Goldhaber, M.B. (1985) The Role of Sulfate-Reducing Bacteria in the Deposition of Sedimentary Uranium Ores. Geomicrobiology Journal, 4, 153-173.

Nakashima, S., Disnar, J.R., Perruchot, A. and Trichet, J. (1984) Experimental-Study of Mechanisms of Fixation and Reduction of Uranium by Sedimentary Organic-Matter under Diagenetic or Hydrothermal Conditions. Geochimica et Cosmochimica Acta, 48, 2321-2329.

National Research Council (2000) Research needs in subsurface science, Vol. National Academy Press, Washington DC.

Neal, A.L., Techkarnjanaruk, S., Dohnalkova, A., McCready, D., Peyton, B.M. and Geesey, G.G. (2001) Iron sulfides and sulfur species produced at hematite surfaces in the presence of sulfate-reducing bacteria. Geochimica et Cosmochimica Acta, 65, 223-235.

Nealson, K.H. and Stahl, D.A. (1997) Microorganisms and biogeochemical cycles: What can we learn from layered microbial communities? In Geomicrobiology: Interactions between microbes and minerals Vol 35(Banfield J.F. and Nealson K.H. Eds.). Mineralogical Society of America, Washington, D.C., 5-34.
Nevin, K.P., Finneran, K.T. and Lovley, D.R. (2003) Microorganisms associated with uranium bioremediation in a highsalinity subsurface sediment. Applied and Environmental Microbiology, 69, 3672-3675.

Nevin, K.P. and Lovley, D.R. (2000) Potential for nonenzymatic reduction of $\mathrm{Fe}(\mathrm{III})$ via electron shuttling in subsurface sediments. Environmental Science \& Technology, 34, 24722478.

North, N.N., Dollhopf, S.L., Petrie, L., Istok, J.D., Balkwill, D.L. and Kostka, J.E. (2004) Change in bacterial community structure during in situ biostimulation of subsurface sediment cocontaminated with uranium and nitrate. Applied and Environmental Microbiology, 70, 4911-4920.

Ortiz-Bernad, I., Anderson, R.T., Vrionis, H.A. and Lovley, D.R. (2004) Resistance of solid-phase U(VI) to microbial reduction during in situ bioremediation of uranium-contaminated groundwater. Applied and Environmental Microbiology, 70, 7558-7560.

Petrie, L., North, N.N., Dollhopf, S.L., Balkwill, D.L. and Kostka, J.E. (2003) Enumeration and characterization of iron(III)reducing microbial communities from acidic subsurface sediments contaminated with uranium(VI). Applied and Environmental Microbiology, 69, 7467-7479.

Pietzsch, K., Hard, B.C. and Babel, W. (1999) A Desulfovibrio sp capable of growing by reducing U(VI). Journal of Basic Microbiology, 39, 365-372.

Roden, E.E. (2003a) Diversion of electron flow from methanogenesis to crystalline Fe(III) oxide reduction in carbon-limited cultures of wetland sediment microorganisms. Applied and Environmental Microbiology, 69, 5702-5706.

Roden, E.E. (2003b) Fe(III) oxide reactivity toward biological versus chemical reduction. Environmental Science \& Technology, 37, 1319-1324.

Roden, E.E. and Wetzel, R.G. (2003) Competition between $\mathrm{Fe}$ (III)-reducing and methanogenic bacteria for acetate in iron-rich freshwater sediments. Microbial Ecology, 45, 252258.

Roden, E.E. and Scheibe, T.D. (2005) Conceptual and numerical model of uranium(VI) reductive immobilization in fractured subsurface sediments. Chemosphere, 59, 617-628.

Sani, R.K., Peyton, B.M., Smith, W.A., Apel, W.A. and Petersen, J.N. (2002) Dissimilatory reduction of $\mathrm{Cr}(\mathrm{VI}), \mathrm{Fe}(\mathrm{III})$, and U(VI) by Cellulomonas isolates. Applied Microbiology and Biotechnology, 60, 192-199.

Senko, J.M., Istok, J.D., Suflita, J.M. and Krumholz, L.R. (2002) In-situ evidence for uranium immobilization and remobilization. Environmental Science \& Technology, 36, 1491-1496.

Senko, J.M., Mohamed, Y., Dewers, T.A. and Krumholz, L.R. (2005a) Role for Fe(III) minerals in nitrate-dependent microbial U(IV) oxidation. Environmental Science \& Technology, 39, 2529-2536.

Senko, J.M., Suflita, J.M. and Krumholz, L.R. (2005b) Geochemical controls on microbial nitrate-dependent U(IV) oxidation. Geomicrobiology Journal, 22, 371-378.

Shelobolina, E.S., Sullivan, S.A., O’Neill, K.R., Nevin, K.P. and Lovley, D.R. (2004) Isolation, characterization, and U(VI)reducing potential of a facultatively anaerobic, acid-resistant bacterium from Low-pH, nitrate- and U(VI)-contaminated subsurface sediment and description of Salmonella subterranea sp nov. Applied and Environmental Microbiology, 70, 2959-2965.

Suzuki, Y. and Banfield, J.F. (1999) Geomicrobiology of uranium. 
In Uranium: mineralogy, geochemistry and the environment (Burns, P.C. and Finch, R. Eds.). Reviews in Mineralogy, Mineralogical Society of America, Washington, D.C., 38, 393-432.

Suzuki, Y., Kelly, S.D., Kemner, K.M., Banfield, J.F. (2002) Radionuclide contamination - Nanometre-size products of uranium bioreduction. Nature, 419, 134-134.

Suzuki, Y., Kelly, S.D., Kemner, K.M. and Banfield, J.F. (2003) Microbial populations stimulated for hexavalent uranium reduction in uranium mine sediment. Applied and Environmental Microbiology, 69, 1337-1346.

Suzuki, Y. and Banfield, J.F. (2004) Resistance to, and accumulation of, uranium by bacteria from a uranium-contaminated site. Geomicrobiology Journal, 21, 113-121.

Suzuki, Y., Kelly, S.D., Kemner, K.M. and Banfield, J.F. (2004) Enzymatic U(VI) ireduction by Desulfosporosinus species. Radiochimica Acta, 92, 11-16.

Suzuki, Y., Kelly, S.D., Kemner, K.M. and Banfield, J.F. (2005) Direct microbial reduction and subsequent preservation of uranium in natural near-surface sediment. Applied and Environmental Microbiology, 71, 1790-1797.

Tebo, B.M. and Obraztsova, A.Y. (1998) Sulfate-reducing bacterium grows with $\mathrm{Cr}(\mathrm{VI}), \mathrm{U}(\mathrm{VI}), \mathrm{Mn}(\mathrm{IV})$, and $\mathrm{Fe}(\mathrm{III})$ as electron acceptors. FEMS Microbiology Letters, 162, 193-198.

Tokunaga, T.K., Wan, J.M., Pena, J., Brodie, E.L., Firestone, M.K., Hazen, T.C., Sutton, S.R., Lanzirotti, A. and Newville, M. (2005) Uranium reduction in sediments under diffusion-limited transport of organic carbon. Environmental Science \& Technology, 39, 7077-7083.

Vrionis, H.A., Anderson, R.T., Ortiz-Bernad, I., O’Neill, K.R., Resch, C.T., Peacock, A.D., Dayvault, R., White, D.C., Long, P.E. and Lovley, D.R. (2005) Microbiological and geochemical heterogeneity in an in situ uranium bioremediation field site. Applied and Environmental Microbiology, 71, 63086318.

Wan, J.M., Tokunaga, T.K., Brodie, E., Wang, Z.M., Zheng, Z.P., Herman, D., Hazen, T.C., Firestone, M.K. and Sutton, S.R. (2005) Reoxidation of bioreduced uranium under reducing conditions. Environmental Science \& Technology, 39, 61626169.

Weber, K.A., Picardal, F.W. and Roden, E.E. (2001) Microbially catalyzed nitrate-dependent oxidation of biogenic solidphase $\mathrm{Fe}(\mathrm{II})$ compounds. Environmental Science \& Technology, 35, 1644-1650.

Wersin, P., Hochella, M.F., Persson, P., Redden, G., Leckie, J.O. and Harris, D.W. (1994) Interaction between Aqueous Uranium(VI) and Sulfide Minerals - Spectroscopic Evidence for Sorption and Reduction. Geochimica et Cosmochimica Acta, 58, 2829-2843.

Wielinga, B., Bostick, B., Hansel, C.M., Rosenzweig, R.F. and Fendorf, S. (2000) Inhibition of bacterially promoted uranium reduction: Ferric (hydr)oxides as competitive electron acceptors. Environmental Science \& Technology, 34, 21902195.

Wildung, R.E., Gorby, Y.A., Krupka, K.M., Hess, N.J., Li, S.W., Plymale, A.E., McKinley, J.P. and Fredrickson, J.K. (2000) Effect of electron donor and solution chemistry on products of dissimilatory reduction of technetium by Shewanella putrefaciens. Applied and Environmental Microbiology, 66, 2451-2460.

Manuscript received March 22, 2006

Manuscript accepted June 8, 2006

Published online November 24, 2006

Manuscript handled by Tsutomu Sato 